\title{
Análise das áreas de preservação permanente e da qualidade da água do Rio Corrente, Corrente/PI
}

O crescimento da população das cidades e suas atividades econômicas aceleram a deterioração da qualidade da água nos corpos hídricos e avançam sobre sua área de preservação. O presente trabalho objetivou-se analisar as Áreas de Preservação Permanente (APPs) do Rio Corrente nas últimas três décadas, verificando o ordenamento jurídico de uso e ocupação do solo urbano, as legislações ambientais e a qualidade da água do mesmo. Nesse contexto, foi realizado um mapeamento nas APPs do Rio Corrente para avaliar as mudanças de uso e ocupação do solo que ocorreram de 1998 a 2018 com base Plano Diretor Municipal. Foi utilizado técnicas de geoprocessamento e a base de dados MapBiomas. Foram encontradas as seguintes classes de cobertura vegetal: pastagem, floresta natural, formação campestre e cultura anual e perene. Em seguida realizou-se a coleta e análise dos parâmetros físico-químicos e microbiológicos da água e confrontados com a Resolução no 357/2005 do Conselho Nacional de Meio Ambiente (CONAMA) e Índice de Qualidade das Águas (IQA). A determinação do IQA resultou em valores que variaram entre 50 e 62 no período seco e 51 a 58 no período chuvoso variando entre aceitável e bom. A APP evoluiu de 39 hectares para 60,8 hectares, demonstrando uma maior preservação pós Plano Diretor Municipal. Se o poder público fiscalizasse efetivamente o resultado poderia ser mais efetivo.

\section{Analysis of the areas of permanent preservation and the quality of the water from the Corrente River, Corrente/PI}

\begin{abstract}
The growth of the population of cities and their economic activities accelerate the deterioration of water quality in water bodies and advance over their preservation area. The present study aimed to analyze the Permanent Preservation Areas (APPs) of the Corrente River in the last three decades, verifying the legal order of use and occupation of urban land, environmental legislation and water quality. In this context, a mapping was carried out in the River Corrente PPAs to assess the changes in land use and occupation that occurred from 1998 to 2018 based on the Municipal Master Plan. Geoprocessing techniques and the MapBiomas database were used. The following classes of vegetation cover were found: pasture, natural forest, countryside formation and annual and perennial culture. Then, the collection and analysis of the physical-chemical and microbiological parameters of the water were carried out and compared with Resolution No. $357 / 2005$ of the National Environment Council (CONAMA) and the Water Quality Index (IQA). The determination of the IQA resulted in values that varied between 50 and 62 in the dry period and 51 to 58 in the rainy period, varying between acceptable and good. The APP evolved from 39 hectares to 60.8 hectares, demonstrating greater preservation after the Municipal Master Plan. If the public authorities effectively inspected the result, it could be more effective.
\end{abstract}

Keywords: Permanent preservation area; Master Plan; Geoprocessing; Water Quality Index; Land use and occupation.

Topic: Desenvolvimento, Sustentabilidade e Meio Ambiente

Reviewed anonymously in the process of blind peer.
Received: $11 / 05 / 2020$

Approved: 04/06/2020
Anaian Antunes Bembem (i)

Instituto Federal do Piauí, Brasil

http://lattes.cnpq.br/9652102577830650

http://orcid.org/0000-0003-3557-6336

anaian@ifpi.edu.br

Leandro Caixeta Salomão (iD

Instituto Federal Goiano, Brasil

http://lattes.cnpq.br/0048021809961606

http://orcid.org/0000-0001-9436-1488

leandro.salomao@ifgoiano.edu.br

Rômulo Vargas Lustosa (ic)

Instituto Federal Goiano, Brasil

http://lattes.cnpq.br/1902042137489859

http://orcid.org/0000-0002-2683-7576

vargas-romulo@hotmail.com

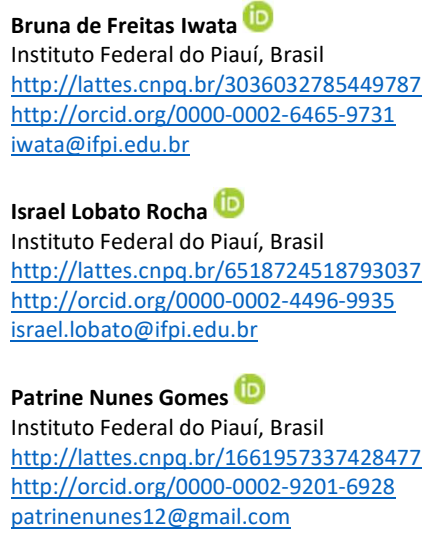

Instituto Federal do Piauí, Brasil

http://lattes.cnpq.br/3036032785449787

http://orcid.org/0000-0002-6465-9731

iwata@ifpi.edu.br

Israel Lobato Rocha (iD

Instituto Federal do Piauí, Brasil

http://lattes.cnpq.br/6518724518793037

http://orcid.org/0000-0002-4496-9935

israel.lobato@ifpi.edu.br

Patrine Nunes Gomes (iD)

Instituto Federal do Piauí, Brasil

http://lattes.cnpq.br/1661957337428477

http://orcid.org/0000-0002-9201-6928

patrinenunes12@gmail.com

Referencing this:

BEMBEM, A. A.; SALOMÃO, L. C.; LUSTOSA, R. V.; IWATA, B. F.; ROCHA, I. L.; GOMES, P. N.. Análise das áreas de preservação permanente e da qualidade da água do Rio Corrente, Corrente/PI. Revista IberoAmericana de Ciências Ambientais, v.11, n.4, p.345-361, 2020. DOI: http://doi.org/10.6008/CBPC2179-6858.2020.004.0028 


\section{INTRODUÇÃO}

A interface homem natureza é fator relevante na modificação da paisagem natural. Lima (2010) destaca que o aumento da população proporciona diretamente o crescimento das cidades, acarretando casos de ocupação urbana em áreas inadequadas, afetando diretamente o ser humano e o meio ambiente do local. Esse crescimento de forma desordenada fez com que os problemas ambientais urbanos fossem aumentando constantemente, necessitando cada vez mais da utilização de ferramentas de monitoramento, surgindo assim, as geotecnologias, favorecendo o monitoramento e o diagnóstico de atividades degradadoras do ambiente, proporcionando uma tomada de decisão técnica e concisa.

Segundo Moreira et al. (2015), devido às diversas modificações que vêm ocorrendo na paisagem natural, tem sido de grande importância fazer o uso de novas tecnologias que sejam capazes de obterem informações mais precisas, como é caso da utilização das geotecnologias que são de grande relevância para monitoramento dos "espaços geográficos", bem como para a fiscalização e cumprimentos das leis existentes.

O uso das ferramentas do Geoprocessamento tem um papel significativo nas atividades de mapeamento, como por exemplo, identificar as Áreas de Preservação Permanente (APPs), gerenciar a ocupação antrópica e diagnosticar os problemas ambientais de determinada área, sendo um recurso estratégico e essencial para a tomada de decisão (FARIAS et al., 2017).

As APPs se encontram regulamentadas em nível Federal na lei 12.651 de 2012, que institui o Código Florestal Brasileiro. Com isso se considera as APPs presentes em zonas rurais ou urbanas, que para os efeitos desta Lei, são as faixas marginais de qualquer curso d'água naturais, perenes e intermitentes, com exceção dos efêmeros, desde a borda da calha do leito regular, com largura mínima de 30 metros, para os cursos d'água de menos de 10 (dez) metros de largura (BRASIL, 2012). Tais áreas são de grande importância uma vez que tem como finalidade proteger o meio ambiente garantindo a segurança dos recursos naturais bem como da biodiversidade presentes nestes espaços.

Importante salientar que as práticas de retirada da cobertura vegetal consequente de mudança de uso e ocupação do solo nas áreas de fragilidade e elevado serviço ambiental de uma bacia hidrográfica, como as APPs, podem proporcionar a diminuição do potencial hídrico nessa bacia, comprometendo toda uma região abastecida por esse manancial. Com isso é relevante ressaltar a necessidade de monitoramento dessas áreas, para detalhamento do estado de conservação e possibilidades de avaliação das perdas (SILVA et al., 2017). Teixeira et al. (2009) relatam que a perda total ou parcial da vegetação influência significativamente na redução da infiltração de água no lençol freático, causando o aumento do escoamento superficial, principalmente nas áreas urbanas construídas, influenciando no subsídio da área geográfica para a avaliação e monitoramento da quantidade de água disponível em uma bacia hidrográfica.

Mesmo com o arcabouço jurídico, a expansão das cidades no Brasil continuou vulnerabilizando as áreas protegidas. No município de Corrente/PI que fica localizado no extremo sul do Piauí e que foi escolhido como área de estudo desta pesquisa não foi diferente, pois a legislação não é respeitada no tocante à proteção das áreas de preservação permanente do rio Corrente. 
Desde o processo de criação da cidade de Corrente/PI, a população se estabeleceu às margens rio Corrente, que corta a mesma, ocasionando assim a supressão da sua mata ciliar e consequentemente alterando o seu leito. Este Rio é considerado de extrema relevância para uma população de quase trinta mil habitantes e ano após ano o mesmo tem diminuído de extensão e em volume de água, conforme informações da Águas e Esgotos do Piauí (Agespisa) o que tem preocupado a população local, visto que a água é um recurso indispensável para a sobrevivência.

Além da legislação Federal, o Município conta com uma legislação municipal voltada para as questões urbanas e ambientais, sendo as leis que regulamentam o uso e ocupação do solo urbano da cidade de Corrente-PI estabelecendo a previsão das áreas que devem ser protegidas, dentre essas leis temos o Plano Diretor (Lei 394 de 2007, Corrente 2008), atualizado em 2018, Lei de Parcelamento Uso e Ocupação do solo urbano (Lei 414 de 2018), e Lei de Proteção, conservação, recuperação e desenvolvimento dos recursos. Entretanto, não existe por parte do poder público uma fiscalização efetiva para diminuição desses danos. Com isso, percebe-se a necessidade de uma aplicação efetiva da legislação para garantir a preservação dessas áreas. Nesse sentido, esse estudo buscou analisar o processo evolutivo de expansão urbana do Município de Corrente-PI sobre as APPs do Rio Corrente e sobre a qualidade dos recursos hídricos, verificando o ordenamento jurídico no âmbito Federal e Municipal.

\section{REVISÃO TEÓRICA}

\section{Legislação Ambiental pertinente}

Desde 2012 vigora no Brasil a lei 12.651/2012 conhecida como o novo Código Florestal, no qual estabelece parâmetros mínimos de extensão das APPs de acordo com a largura do leito do rio, tendo como referência a borda da calha do leito regular conforme está presente no art.4을 inciso I e II desta referida lei:

I - As faixas marginais de qualquer curso d'água natural perene e intermitente, excluídos os efêmeros, desde a borda da calha do leito regular, em largura mínima de:

a) 30 (trinta) metros, para os cursos d'água de menos de 10 (dez) metros de largura;

b) 50 (cinquenta) metros, para os cursos d'água que tenham de 10 (dez) a 50 (cinquenta) metros de largura;

c) 100 (cem) metros, para os cursos d'água que tenham de 50 (cinquenta) a 200 (duzentos) metros de largura;

d) 200 (duzentos) metros, para os cursos d'água que tenham de 200 (duzentos) a 600 (seiscentos) metros de largura;

e) 500 (quinhentos) metros, para os cursos d'água que tenham largura superior a 600 (seiscentos) metros;

II - As áreas no entorno dos lagos e lagoas naturais, em faixa com largura mínima de:

a) 100 (cem) metros, em zonas rurais, exceto para o corpo d'água com até 20 (vinte) hectares de superfície, cuja faixa marginal será de 50 (cinquenta) metros;

b) 30 (trinta) metros, em zonas urbanas (BRASIL, 2012).

Sendo assim o rio Corrente se enquadraria na primeira classe de APP, devendo ser preservada 30 metros na sua margem direita e 30 metros na sua margem esquerda. No entanto, a legislação Municipal estabelece no seu Plano Diretor, Lei 394 de 2007 no seu artigo 14, inciso I alínea b que a APPs do mesmo 
deve ser de 100 metros conforme reprodução abaixo:

Art 14: Para a preservação e recuperação do meio ambiente considerado bem de uso comum e essencial à vida, ficam estabelecidos os seguintes objetivos específicos:

I- Manter equilibrado o meio ambiente, urbano e rural, mediante as seguintes ações:

b) Preservar e recuperar as Áreas de Preservação Permanente do rio Corrente e Paraim, e riachos Toboquinha e Buritizinho, observando as faixas laterais mínimas de 100 metros ao longo dos rios e de 50 metros ao longo dos riachos (BRASIL, 2007).

Dessa forma, deve-se levar em consideração a Legislação mais protecionista ao meio ambiente, no caso a Municipal. Vale ressaltar que a Lei Federal estabelece apenas o mínimo de área a ser protegida, podendo o Município aumentar visando uma maior proteção ao meio ambiente, sendo assim vigora o princípio pacificado pela doutrina e jurisprudência do in dubio pró ambiente (BONAVIDES, 2017).

Já no que diz respeito à água a Lei 9.433/97 que institui a Política Nacional de Recursos Hídricos também conhecida como Lei das águas, descreve a gestão das águas no Brasil como a responsabilidade para que seja promovida a garantia dos usos múltiplos dos recursos hídricos. Possui o objetivo de controlar os usos dos recursos hídricos e o meio ambiente. Em relação à Constituição Federal e a Lei n 6.938, de 31 de agosto de 1981, estas visam controlar o lançamento de poluentes no meio ambiente e proíbe o lançamento em níveis nocivos ou perigosos que ofereçam riscos aos seres vivos, ao bem-estar humano e ao equilíbrio ecológico aquático (ROCHA et al., 2016). Já a resolução 357/2005 do CONAMA, vem dispor sobre os teores máximos de nutrientes em corpos hídricos, sendo uma forma de monitorar a qualidade dos parâmetros das mesmas buscando manter qualidade da água para seus usos múltiplos.

\section{MATERIAIS E MÉTODOS}

\section{Área de estudo}

A pesquisa foi realizada no município de Corrente localizado no Extremo Sul Piauiense, entre as coordenas geográficas $10^{\circ} 15^{\prime}$ e $10^{\circ} 35^{\prime}$ de latitude sul e $44^{\circ} 50^{\prime}$ e $45^{\circ} 30^{\prime}$ de longitude oeste (Mapa 1). Corrente limita-se com os municípios de São Gonçalo do Gurguéia, Riacho Frio, Cristalândia do Piauí, Parnaguá, Sebastião Barros e Formosa do Rio Preto/BA. O município possui uma população de 26.644 habitantes de acordo com estimativas do IBGE de 2019 e contém uma área de unidade territorial de $\mathrm{km}^{2}$ 3.048,447km (IBGE, 2019).

A vegetação nesta região é majoritariamente composta por campo cerrado e caatinga arbórea e arbustiva (SANO et al., 2010). O clima é tropical semiúmido com o período de cinco meses de estação seca. E apresenta temperaturas mínimas médias de $20^{\circ} \mathrm{C}$ e máximas de $34^{\circ} \mathrm{C}$ e precipitação pluviométrica acumulada anual de 980 mm (INMET, 2019).

Com relação ao relevo, a cidade foi construída em uma região predominantemente plana, sendo seu território cortado por chapadões planos ou levemente ondulado, limitado por paredes escarpadas que podem atingir até $600 \mathrm{~m}$, abaixo dos quais podem ser observados vales rebaixados e planos (SILVA, 2018). 0 estudo foi realizado especificamente no trecho urbano da Área de Preservação Permanente (APPs) do rio Corrente, na cidade de Corrente/PI. 


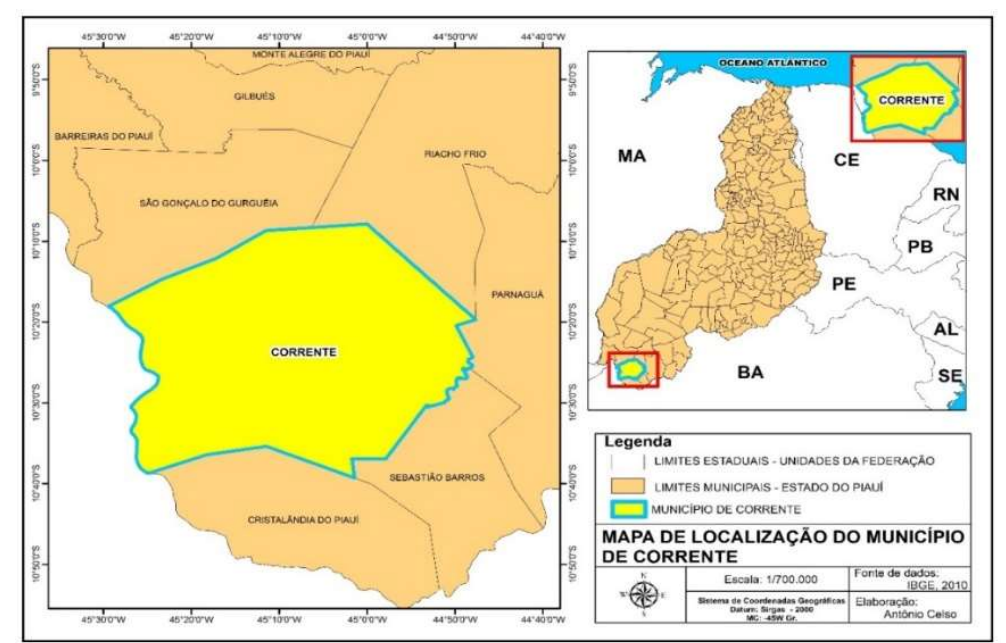

Mapa 1: Localização do município de Corrente/PI. Fonte: Leite (2010). ${ }^{1}$

O Rio corta a cidade e é a principal fonte de abastecimento da população, possui $66 \mathrm{~km}$ e faz parte da bacia hidrográfica do rio Paraim que se encontra dentro da região hidrográfica do rio Parnaíba. Ele está assentado sobre as seguintes estruturas geológicas: Formação Urucuia, Formação Areado, Grupo Serra Grande, depósitos aluvionares, coberturas detrito-lateríticas ferruginosas e Complexo Cristalândia do Piauí (MORAIS, 2013). O seu perímetro urbano é de $5,45 \mathrm{Km}$, área que é objeto do presente estudo (Mapa 2). 0 rio Corrente é considerado, segundo a Resolução CONAMA 357/05, como de classe 2. Essa classificação foi baseada no Art. 42, capítulo 6 da referida resolução, que diz: "enquanto não aprovados os respectivos enquadramentos, as águas doces serão consideradas Classe 2" (BRASIL, 2005).

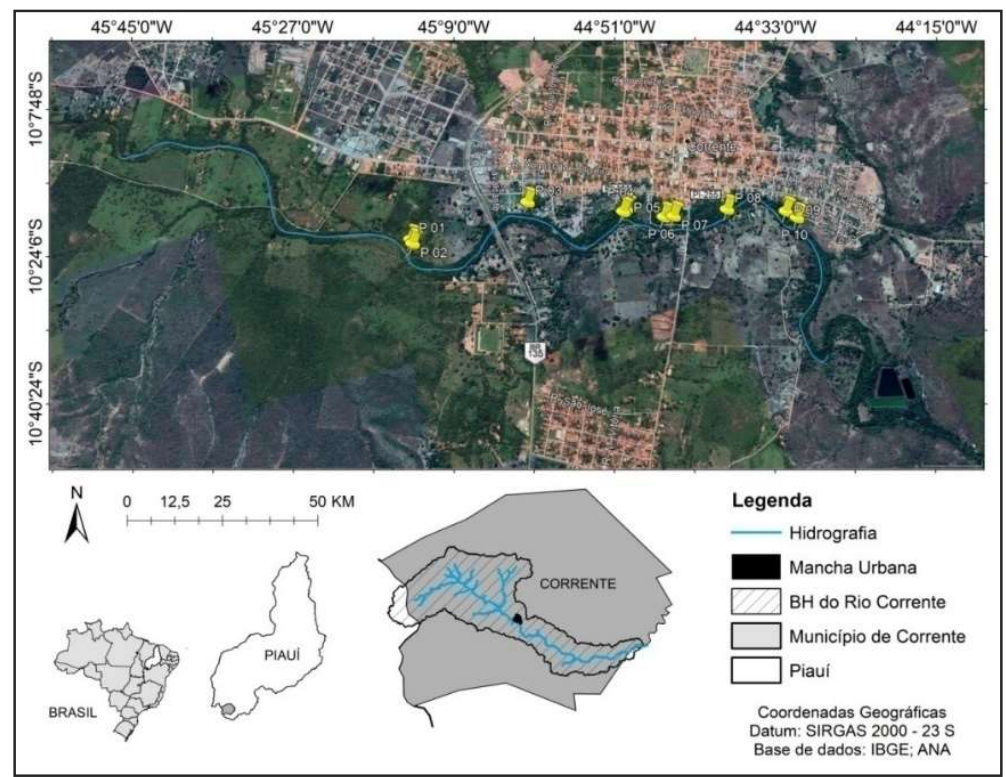

Mapa 2: Áreas de preservação permanente do município de Corrente, Piauí.

\section{Procedimentos metodológicos}

\section{Identificação dos pontos}

${ }^{1}$ LEITE, A. C. S.. Mapa de Localização do Município de Corrente. 2016. Mapa político. Escala 1:700.000. Não publicado. (Mapa produzido pelo autor, técnico em Geoprocessamento e docente do IFPI, com base em dados do IBGE de 2010). 
Para realização desta pesquisa foram realizadas visitas in loco no perímetro urbano do rio Corrente no mês de março de 2019, percorrendo um total de $5,45 \mathrm{~km}$. No qual foram identificados 10 pontos amostrais (Figura 2), levando em consideração a disposição dos mesmos dentro do perímetro urbano da área mais e menos povoada e também a facilidade de acesso. Vale ressaltar que em alguns locais a vegetação é fechada impossibilitando o acesso ao mesmo. A obtenção dos dados espaciais em campo (coordenadas) ocorreu com o uso de receptor GPS (Sistema de Posicionamento Global) e posteriormente foram elaborados mapas temáticos da área de estudo com o Arc GIS versão 10.5 que consiste em um Sistema de Informações Geográficas (SIG). Para o desenvolvimento dos mesmos foram utilizadas as malhas municipais do IBGE, bem como arquivos de forma vetorial dos corpos hídricos disponibilizados pela ANA do ano de 2018.

\section{Grau de conservação ambiental da APPs do Rio Corrente}

Para avaliar o grau de conservação da área foi utilizada a base de dados do MapBiomas, coleção 4, onde incluí dados anuais de cobertura e uso do solo que são utilizados para o monitoramento de uso e ocupação do solo, bem como a mensuração da área de preservação. O processo de geração das imagens para avaliação do trecho levou em consideração três períodos de análises, inicialmente o ano de 1998, dez anos antes da implementação do Plano Diretor Municipal, 2008 no ano da entrada em vigor do Plano e 2018, ano em que o mesmo completou 10 anos, e teve início à reformulação conforme estabelece o Estatuto da Cidade (BRASIL, 2001).

\section{Quantificação das áreas}

Considerando o predisposto no Código Florestal Brasileiro e Plano Diretor Municipal, foram quantificadas as áreas em atendimento aos limites de uso e preservação das áreas de APPs do Rio Corrente, no seu trecho urbano. Para marcação dos limites das APPs foi gerado um buffer com 100 metros, tendo como referência a Lei Municipal № 394 de 2008, em seguida utilizou a base de dados do MapBiomas coleção 4 para identificar as classes de cobertura do solo para os anos de 1998, 2008 e 2018, onde foram gerados mapas temáticos de cada um desses anos citados e, por fim, a quantificação das classes.

\section{Avaliação da qualidade da água}

Para a coleta e análise da qualidade da água do Rio Corrente no seu perímetro urbano foram estabelecidos 10 pontos (Figura 2), começando da área menos urbanizada, sendo os três primeiros pontos, até a área de maior concentração urbana. As mesmas foram realizadas em dois períodos, em junho de 2019 (período seco) e novembro de 2019 (período chuvoso), no qual se levou em consideração a variabilidade sazonal, que teve como referência as informações pluviométricas disponibilizadas pelo Instituto Nacional de Meteorologia na estação automática localizada no Campus do Instituto Federal do Piauí na cidade de Corrente (PI), código A374 na Latitude -1042'91" e Longitude -45¹7'30", com dados do ano de 2019 (INMET, 2019) (Figura 1). 


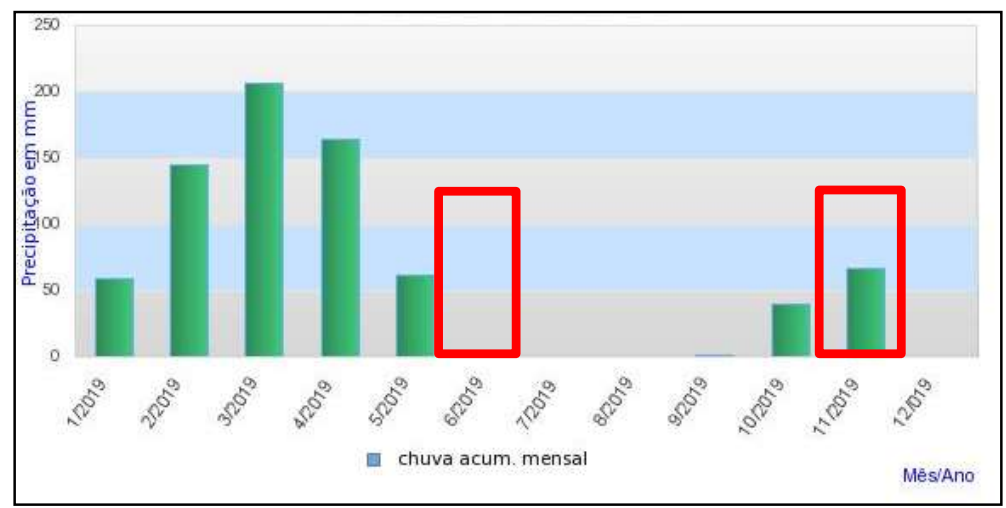

Figura 1: Precipitação mensal (ano de 2019) na Estação Pluviométrica de Corrente/PI. Fonte: INMET (2019).

Após a coleta, as amostras foram acondicionadas e preservadas conforme o Guia Nacional de Coleta e Preservação de Amostras de Água (CETESB et al., 2011). Os parâmetros físico-químicos e microbiológicos constituintes do IQA (Índice de Qualidade das Águas) analisados foram: oxigênio dissolvido (OD), coliformes termotolerantes $(\mathrm{CT})$, potencial hidrogeniônico $(\mathrm{pH})$, temperatura, turbidez, fósforo, nitrogênio total, resíduo total e demanda bioquímica de oxigênio (DBO) dentro do prazo estabelecido de 12 horas para a realização da mesma. As amostras foram encaminhadas para o laboratório de Água e Solos do Instituto Federal do Piauí - Campus Corrente, analisadas conforme método de referência Standard Methods da Associação Americana de Saúde Pública (APHA, 2012) (Tabela 1).

Tabela 1: Informações sobre as metodologias das análises laboratoriais, equipamentos adotados e unidades de medida das análises dos parâmetros físico-químicos e microbiológicos.

\begin{tabular}{l|l|l}
\hline Parâmetro & Método/Equipamento & Unidade de medida \\
\hline Oxigênio dissolvido & Oxímetro (Lutron) - DO-5519 & $\mathrm{mg} / \mathrm{L}$ \\
\hline Temperatura & Termômetro digital - TE07 & ${ }^{\circ} \mathrm{C}$ \\
\hline Coliformes termot. & Meio cromogênio em DIP em papel - Colipaper & $\mathrm{NPM} / 100 \mathrm{~mL}$ \\
\hline $\mathrm{pH}$ & pHmetro (Lutron) - PH 221 & - \\
\hline DBO & Método volumétrico (Alfakit) & $\mathrm{mg} / \mathrm{L}$ \\
\hline Nitrogênio total & Fotocolorímetro (Alfakit) & $\mathrm{mg} / \mathrm{L}$ \\
\hline Fósforo total & Fotocolorímetro (Alfakit) & $\mathrm{mg} / \mathrm{L}$ \\
\hline Turbidez & Turbidimetro microprocessador (Alfakit) & $\mathrm{UNT}$ \\
\hline Resíduo total & Método gravimétrico & $\mathrm{mg} / \mathrm{L}$ \\
\hline
\end{tabular}

Após a coleta as amostras foram acondicionadas e posteriormente feitas às análises de todos os parâmetros presentes na tabela 1 .

\section{Índice de Qualidade de Água- IQA}

A partir de um estudo realizado em 1970 pela 'National Sanitation Foundation' dos Estados Unidos, a CETESB adaptou e desenvolveu o IQA - Índice de Qualidade das Águas que incorpora nove variáveis consideradas relevantes para a avaliação da qualidade das águas, tendo como determinante principal a sua utilização para abastecimento público. A criação do IQA baseou-se numa pesquisa de opinião junto a especialistas em qualidade de águas, que indicaram as variáveis a serem avaliadas, o peso relativo e a condição com que se apresentam cada parâmetro, segundo uma escala de valores. Das 35 variáveis indicadoras de qualidade de água inicialmente propostos, somente nove foram selecionados. Para estes, a critério de cada profissional, foram estabelecidas curvas de variação da qualidade das águas de acordo com 
o estado ou a condição de cada parâmetro (CETESB, 2018). Estas curvas de variação, sintetizadas em um conjunto de curvas médias para cada parâmetro, bem como seu peso relativo correspondente. Cada parâmetro possui um gráfico de curva média. No eixo das ordenadas encontra-se o valor de qualidade (q) (Figura 2).
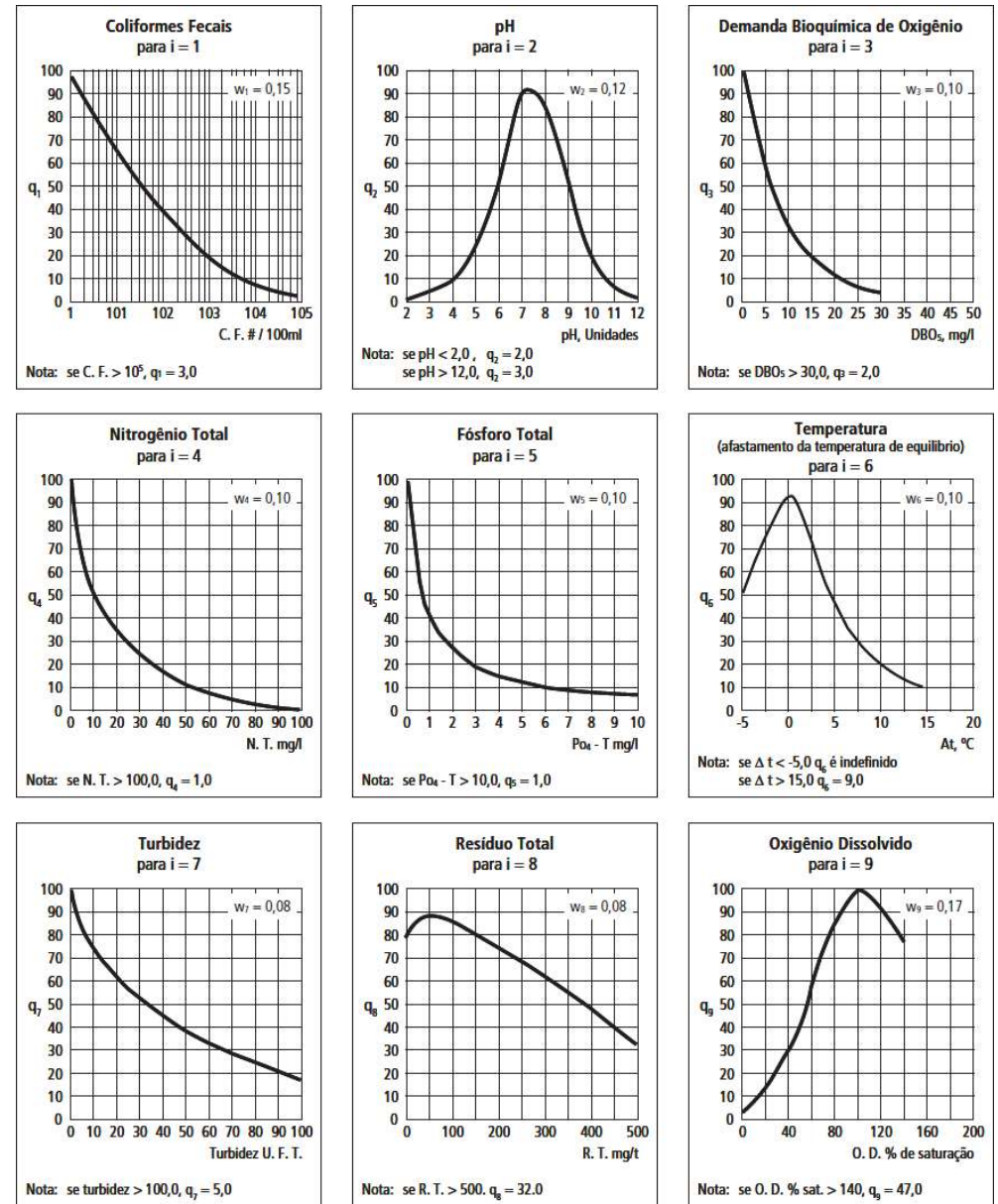

Figura 2: Curvas médias de variação dos parâmetros de qualidade das águas. Fonte: ANA (2004); CETESB (2018).

Para o cálculo do IQA foi constituída uma pontuação de qualidade (q). O resultado da pontuação final varia de 0 a 100 para cada um dos parâmetros de qualidade que compõem o índice. A qualidade (q) é elevada à ponderação (w) correspondente à importância da variável. O IQA é obtido multiplicando-se cada componente (qw) (CETESB, 2018). Para o cálculo do IQA utilizou-se a Equação 1.

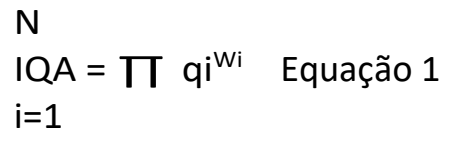

Onde:

IQA - Índice de Qualidade das Águas (varia de 0 a 100); qi - qualidade do parâmetro i-ésimo, obtido através da curva média de variação de qualidade de cada parâmetro, em função do valor obtido; wi - é o peso atribuído ao i-ésimo parâmetro, peso atribuído em função da sua relevância; $\mathrm{n}$ - número de parâmetros $(\mathrm{n}=9)$.

Para a realização do cálculo de IQA foi utilizado programa QualiGraf, software livre da Fundação Cearense de Meteorologia e Recursos Hídricos (FUNCEME, 2018). Após a realização do cálculo, pode-se determinar o IQA das nascentes amostradas, conforme a variação de qualidade (Tabela 2). 
Tabela 2: Classificação do IQA conforme o nível de qualidade.

\begin{tabular}{lll}
\hline \multicolumn{1}{c}{ Classe } & Categoria & \multicolumn{1}{c}{ Ponderação } \\
\hline A & Ótimo & $79<\mathrm{IQA} \leq 100$ \\
\hline B & Bom & $51<\mathrm{IQA} \leq 79$ \\
\hline C & Aceitável & $36<\mathrm{IQA} \leq 51$ \\
\hline D & Ruim & $19<\mathrm{IQA} \leq 36$ \\
\hline E & Péssima & IQA $\leq 19$ \\
\hline
\end{tabular}

Fonte: CETESB (2018).

\section{RESULTADOS E DISCUSSÃO}

\section{Uso do solo na Área de Preservação Permanente}

A confecção dos mapas permitiu avaliar o grau de conservação da Área de Preservação Permanente (APPs) do rio Corrente, nos quais os resultados obtidos por meio de cruzamento tabular dos mapas da APPs e de uso e cobertura da terra no ano de 1998 se encontram na Figura 3.

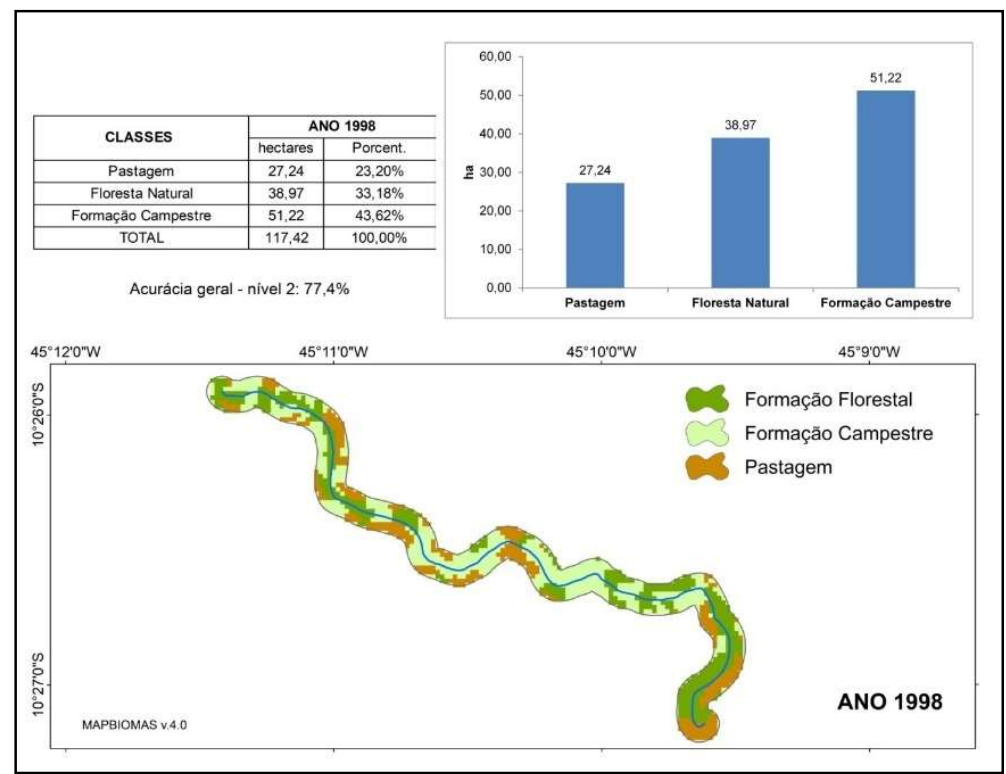

Figura 3: Área de Preservação Permanente (APPs) do Rio Corrente e suas Classes de cobertura vegetal.

Dentre as classes de uso e ocupação das terras encontradas na APPs do rio corrente, no ano de 1998, há predomínio da formação campestre ocupando um total de 51,22 hectares, em seguida a floresta natural com 38,97 hectares e por último as pastagens com um total de 27,24 hectares. Em termos proporcionais, $76,8 \%$ da área encontram-se fora dos padrões da legislação, o que equivale a 78,45 hectares.

As áreas de pastagens eram usadas para a criação de bovinos e equinos, causando compactação dos solos e contaminando as águas. Amaral et al. (2018), faz um alerta dos problemas causados pelo uso do solo de APPs para pastagem, segundo ele os solos ficam vulneráveis à ação erosiva, que consequentemente, poderá causar, por conta da proximidade do corpo d'água, um assoreamento deste rio.

A prática da criação de gado de corte no entorno dos corpos hídricos é comum na região, até porque a pecuária é uma das suas principais matrizes econômicas desde a sua colonização até os dias atuais como pode ser verificado nos dados de 2014 da Agência de Defesa Agropecuária do Piauí (ADAPI), o município possuía um total de 99, 794 cabeças de gado, sendo, portanto, a maior população bovina do estado do Piauí 
(ADAPI, 2014). Por ser uma cidade que apresenta um potencial econômico voltado para a agricultura e pecuária é bem previsível encontrar-se essa classe de pastagem. No que diz respeito à formação campestre, vale destacar que por ser uma área de cerrado, essa vegetação pode ser classificada como uma área de transição.

O segundo período temporal que foi analisado é o ano de 2008, período em que entrou em vigor a lei Municipal 394, Plano Diretor Municipal, estabelecendo a metragem de preservação e as ações de fiscalização e educação ambiental voltadas para a preservação dos corpos hídricos. Nesse segundo período observa-se uma modificação na imagem e nas proporções da APPs (Figura 4).

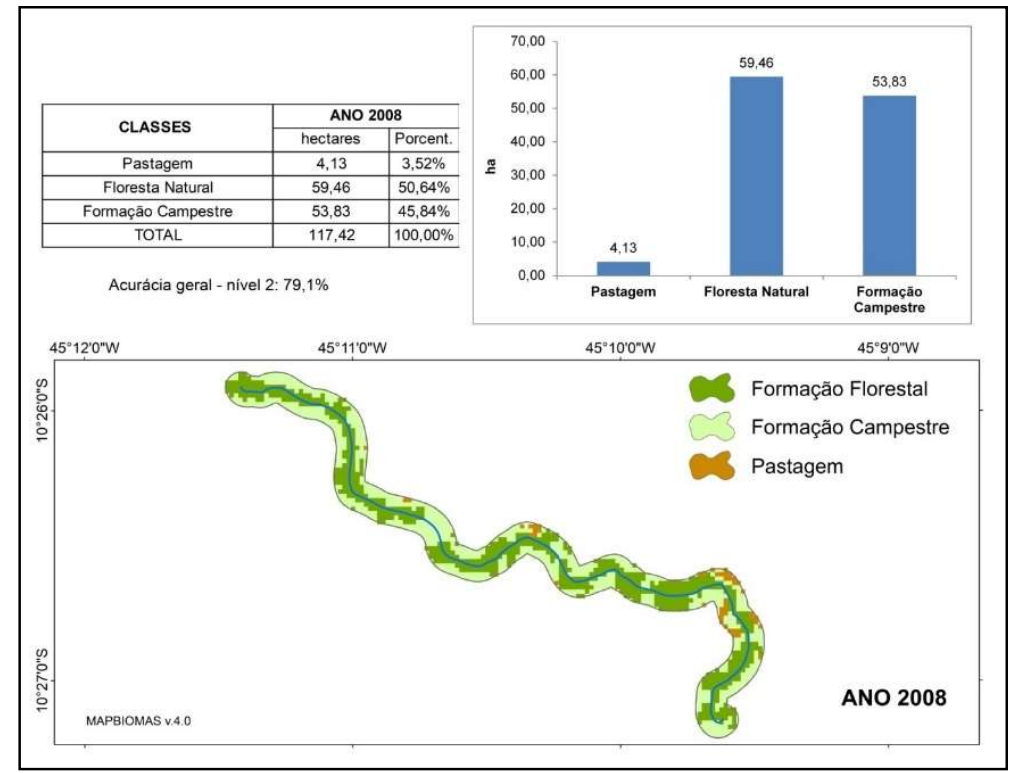

Figura 4: Mapa de Área de Preservação Permanente (APPs) ano de 2008.

Percebe-se a diminuição das pastagens no qual isso pode estar associado ao crescimento da cidade o que acabou fazendo com que essas 'roças' ficassem dentro do perímetro urbano. Além do mais, com o Plano Diretor e a Lei de Zoneamento Urbano, as atividades deveriam ser setorizadas. Apesar de não ser totalmente seguida pela população e não haver fiscalização do poder público. Ocorreu um aumento considerável da classe floresta natural passando de 38,97 hectares para 59,46 hectares, ultrapassando a formação campestre que também subiu de 51,22 hectares para 53,83 hectares, sendo esse aumento proporcionado pela diminuição das pastagens. Sendo assim, 59.46\% está dentro dos padrões estabelecidos pela legislação. Com isso, em dez anos tivemos um aumento da APPs do rio Corrente.

A última década a ser analisada foi a de 2018, período em que o Plano Diretor completa 10 anos e de acordo com a legislação deveria ser reformulado, o que só foi efetivado no ano de 2019. A figura traz as classes de cobertura do solo, quantidades de hectares e percentuais (Figura 5). Na Figura 5 se observa o surgimento de uma quarta classe de cobertura do solo que é a de cultura anual e perene correspondendo 1,8 hectares, está se deve ao fomento de recursos para a economia familiar através de financiamento dos bancos públicos. Fica claro na figura de satélite, no destaque da agricultura, a horta comunitária que fica dentro da área de APPs do rio Corrente.

Ocorre também o crescimento da classe de pastagem de 4,1 hectares para 12,8 hectares, já a classe 
de formação campestre cai de 53,8 hectares para 42 hectares. E a classe de floresta natural tem um leve aumento de 59,5 hectares para 60,78 hectares. Em termos proporcionais 51,76\% do território encontra-se dentro dos padrões da legislação. Essa é uma tendência nos trabalhos realizados como, por exemplo, Fonsêca (2019) no açude Pataxó no Rio Grande do Norte que apresentou índices semelhantes de preservação.

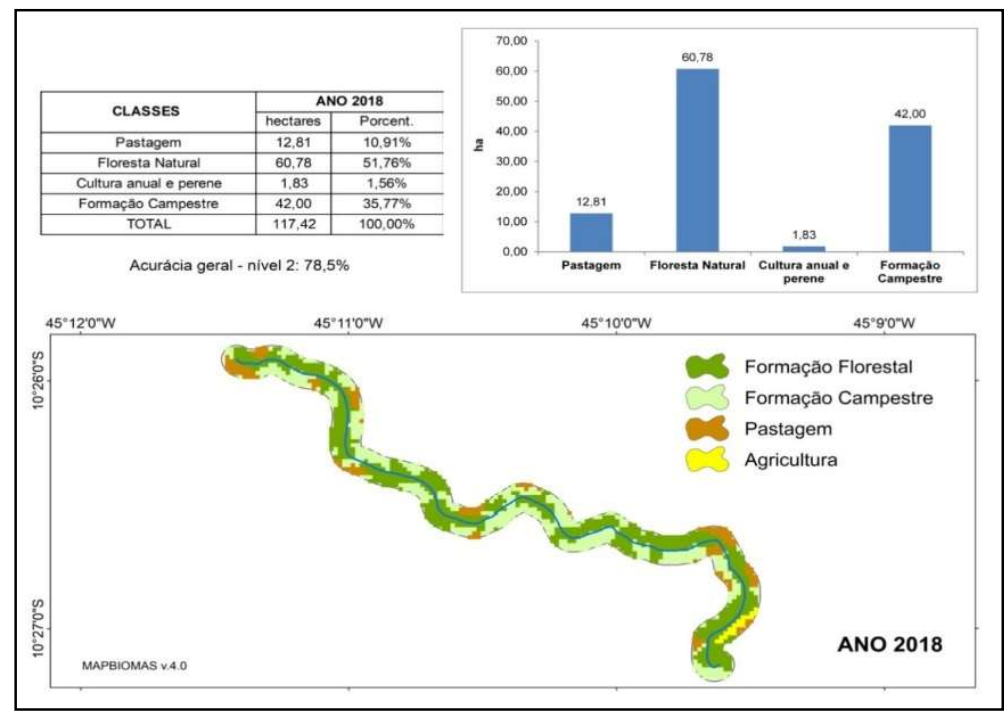

Figura 5: Mapa da Área de Preservação Permanente (APPs) ano de 2018.

A Figura 6 faz uma comparação com os dados das classes de vegetação da APPs e dos respectivos anos analisados. Demonstrando uma evolução no aumento de área preservada, apesar disso ainda estamos bem distante do respeito à legislação. Percebe-se que esse aumento da APPs através das florestas naturais foi um movimento espontâneo. No estudo realizado por Amaral et al. (2018), na área de APPs do rio São João de Tiba situado na cidade de Eunapólis na Bahia, foi apontado que essa não preservação das APPs é comum em várias regiões, onde nesta pesquisa apenas $67,4 \%$ encontrava-se dentro da legislação.

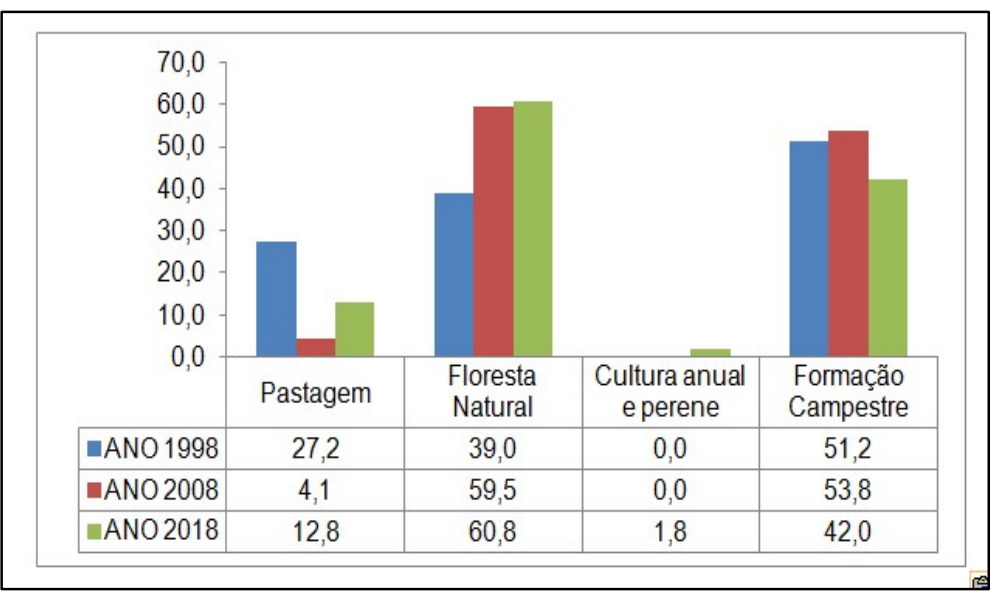

Figura 6: Comparação das classes de vegetação da Área de Preservação Permanente APPs do Rio Corrente.

Mesmo não estando cumprindo totalmente a legislação, a APPs do Rio Corrente vem crescendo década a década. Essa tendência também foi constatada no trabalho de Fonsêca (2019) realizado no Rio Grande do Norte, que constatou uma mudança no uso e ocupação do solo na APPs entre 2008 e 2016, no qual foi possível observar que ocorreu um crescimento significativo da área com Vegetação, no qual antes era de $49,8 \%$ e com o decorrer dos anos passou para $70,7 \%$, o que pode indicar que houve uma maior 
conservação da área. No estudo Campagnolo (2013), no seu trabalho sobre o Rio Arroio no Rio Grande do Sul, encontrou dados semelhantes ao desta pesquisa com um total de 110,4hectares de APPs demarcada, sendo que $56,6 \%$ são formados por matas nativas, percentual considerado relativamente alto pela autora.

\section{Qualidade das águas do trecho urbano do Rio Corrente}

As análises dos parâmetros físico-químicos e microbiológicos da primeira coleta que foram realizadas no período seco, resultaram na alteração de alguns parâmetros como, por exemplo, fósforo total, coliformes termotolerantes e Demanda Bioquímica de Oxigênio (DBO), já os demais se apresentam dentro dos padrões exigidos. Padrões esses que foram baseados na resolução do Conselho Nacional do Meio Ambiente CONAMA no 357 de 2005 (BRASIL, 2005), que dispõe sobre a classificação dos corpos de água conforme a classe de enquadramento, que no caso do rio Corrente se enquadra na classe 2.

O Oxigênio Dissolvido (OD) apresentou em todos os pontos coletados valores dentro dos padrões estabelecidos, (Tabela 3) variando de 7,2 a 8,5 mg/L. Para Vieira (2015), o OD em baixas concentrações pode indicar uma alta atividade biológica, em decorrência do alto teor de matéria orgânica no corpo hídrico, que podem ser provenientes de lançamento de esgoto doméstico sem nenhum tipo de tratamento.

Nos pontos 5, 6 e 8 (tabelas 3) a DBO apresentou valores acima dos padrões estabelecidos pela resolução CONAMA no 357 de 2005. A DBO é uma variável que vai indicar a quantidade de oxigênio dissolvido que é necessário para realizar a biodegradação da matéria orgânica. Quanto maior for os valores de DBO maior será a redução do OD comprometendo a vida aquática (AMÂNCIO et al., 2018).

Os parâmetros como nitrogênio total, turbidez, resíduo total e temperatura encontra-se em conformidade com a resolução no 357/2005 do CONAMA. No entanto, o fósforo total apresentou em todos os pontos analisados, valores acima do limite recomendado, com concentrações que variaram de 1,17 a 6,93 $\mathrm{mg} / \mathrm{L}$ (Tabela 3). Essas variações podem ser explicadas pelo fato de alguns pontos se localizarem em locais próximos a residências com despejos de efluentes e criação de animais, e até próximos a pequenos plantios de agricultura familiar que possivelmente fazem o uso de fertilizantes.

Em grandes quantidades o fósforo, favorece o crescimento de plantas aquáticas, transformando seu aspecto natural, interferindo no sistema químico da água, provocando ainda a eutrofização que pode alterar a composição das espécies do ambiente aquático (ABREU et al., 2018).

Os coliformes termotolerantes apresentaram valores altos em todos os pontos (Tabela 3 ) justamente pelo fato da interferência humana na área urbana e vestígios de animais em locais menos urbanizados. 0 grupo coliforme com suas bactérias é considerado os principais responsáveis pela contaminação fecal dos corpos hídricos, pois essas bactérias são restritas a animais de sangue quente (CARVALHO, 2011).

O pH em todos os pontos está de acordo com os padrões estabelecidos pela resolução CONAMA 357, variando de 5 a 9 (Tabelas 3) considerando que esse parâmetro é importante para a manutenção da vida aquática. Segundo Vieira (2015), o pH é um dos responsáveis por dissolver substâncias na água, como por exemplo, sais metálicos, além de influenciar também na predominância de algumas espécies e ainda nos processos de sedimentação de metais e substancias na água. 
Tabela 3: Parâmetros físico-químicos e Microbiológicos da primeira campanha de coleta de água - Período Seco. Fonte: Pesquisa de campo.

\begin{tabular}{|c|c|c|c|c|c|c|c|c|c|c|c|c|}
\hline \multicolumn{13}{|c|}{ Pontos de coleta** } \\
\hline Parâmetro & Unid.* & P 1** & $\begin{array}{l}\mathbf{P} \\
2^{* *}\end{array}$ & $\begin{array}{l}\mathbf{P} \\
3 * *\end{array}$ & $\begin{array}{l}P \\
4 * *\end{array}$ & $\begin{array}{l}\mathbf{P} \\
5 * *\end{array}$ & P 6** & $\begin{array}{l}\mathbf{P} \\
7 * *\end{array}$ & $\begin{array}{l}\mathrm{P} \\
8^{* *}\end{array}$ & P 9** & $\begin{array}{l}\mathrm{P} \\
10 * *\end{array}$ & $\begin{array}{l}\text { VMP } \\
* * *\end{array}$ \\
\hline OD & $\mathrm{mg} / \mathrm{L}$ & 8,2 & 7,8 & 8 & 7,3 & 8,2 & 8,5 & 8 & 7,2 & 7,2 & 8 & $\geq 5$ \\
\hline DBO & $\mathrm{mg} / \mathrm{L}$ & 2,4 & 2,5 & 2,6 & 2,5 & 11,7 & 7 & 6 & 7,5 & 4,5 & 2,4 & Até 5 \\
\hline $\begin{array}{l}\text { Temperatu } \\
\text { ra }\end{array}$ & ${ }^{\circ} \mathrm{C}$ & 19,9 & 19,8 & 20,3 & $\begin{array}{l}19 \\
6\end{array}$ & 19,4 & 19,9 & 19,8 & 19,8 & 19,8 & 20,2 & - \\
\hline $\begin{array}{l}\text { Fósforo } \\
\text { total }\end{array}$ & $\mathrm{mg} / \mathrm{L}$ & $\begin{array}{l}1,1 \\
7 \\
\end{array}$ & 3,14 & 4,93 & $\begin{array}{l}3,5 \\
9 \\
\end{array}$ & 6,93 & 5,06 & 6,6 & 3,73 & 5,43 & 2,9 & $\leq 0,1$ \\
\hline $\mathrm{Ph}$ & & 7 & 6 & 6 & 6 & 7 & 6 & 5 & 6 & 6 & 6 & 6 a 9 \\
\hline Turbidez & UNT & 6,75 & $\begin{array}{l}10,1 \\
6 \\
\end{array}$ & 5,99 & $\begin{array}{l}9,7 \\
1 \\
\end{array}$ & $\begin{array}{l}19,8 \\
3 \\
\end{array}$ & 6,62 & 4,25 & $\begin{array}{l}13,0 \\
4 \\
\end{array}$ & 4,47 & $\begin{array}{l}4,4 \\
1 \\
\end{array}$ & $\begin{array}{l}\text { Até } \\
100\end{array}$ \\
\hline $\begin{array}{l}\text { Nitrogênio } \\
\text { Total }\end{array}$ & $\mathrm{mg} / \mathrm{L}$ & 0,48 & 0,58 & 0,58 & $\begin{array}{l}0,2 \\
1 \\
\end{array}$ & 0,88 & 0,45 & 0,64 & 1,92 & 1,65 & $\begin{array}{l}0,8 \\
9 \\
\end{array}$ & $\begin{array}{l}\text { Até } \\
2,18\end{array}$ \\
\hline $\begin{array}{l}\text { Resíduo } \\
\text { total }\end{array}$ & $\mathrm{mg} / \mathrm{L}$ & 15,41 & $\begin{array}{l}16,0 \\
8 \\
\end{array}$ & $\begin{array}{l}15,4 \\
1 \\
\end{array}$ & $\begin{array}{l}20 \\
1 \\
\end{array}$ & $\begin{array}{l}98,4 \\
9 \\
\end{array}$ & $\begin{array}{l}22,1 \\
1 \\
\end{array}$ & $\begin{array}{l}22,1 \\
1 \\
\end{array}$ & 20,1 & $\begin{array}{l}22,7 \\
8 \\
\end{array}$ & $\begin{array}{l}20 \\
1 \\
\end{array}$ & $\begin{array}{l}\text { Até } \\
500\end{array}$ \\
\hline C.T. & $\begin{array}{l}\text { UFC/100 } \\
\mathrm{MI}\end{array}$ & 400 & 720 & 960 & 800 & 6960 & 3120 & 2160 & $\begin{array}{l}304 \\
0\end{array}$ & $\begin{array}{l}280 \\
0\end{array}$ & $\begin{array}{l}224 \\
0 \\
\end{array}$ & $\begin{array}{l}\text { Ausent } \\
\mathrm{e}\end{array}$ \\
\hline
\end{tabular}

Na segunda coleta realizada no período chuvoso houve um aumento dos valores da DBO praticamente em todos os pontos analisados (Tabela 4). As altas concentrações de DBO podem acontecer em decorrência do consumo de OD, pelos nutrientes como fósforo e matéria orgânica florestal (ROCHA et al., 2019). De acordo com Santos et al. (2018) as grandes concentrações de DBO de um corpo hídrico são causadas por excessivos consumos de matéria orgânica, que podem ser oriundas tanto de efluentes domésticos de residências próximas ao rio como de folhagem das árvores que existem das áreas de APPs.

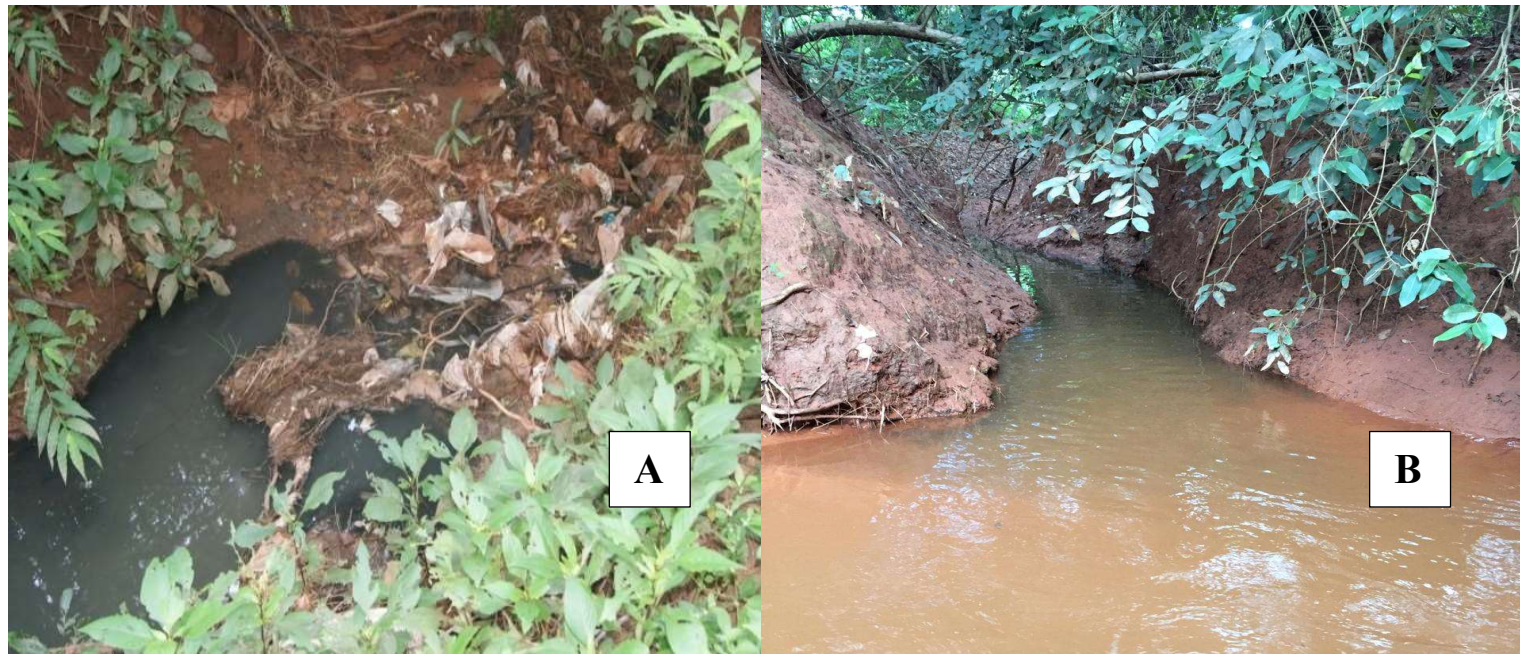

Figura 7: A e B- Local de coleta da amostra do ponto 5.

Os parâmetros fósforo totais e coliformes termotolerantes que já estavam alterados no período seco (Tabela 3), aumentaram no período chuvoso (Tabela 4), esse aumento pode estar atrelado ao aumento do índice pluviométrico do período chuvoso que acaba influenciando nas altas concentrações desses parâmetros, por conta do escoamento superficial que aumenta nesse período e acaba carreando para dentro do rio, materiais de lugares distantes tanto de origem natural como de origem antrópicas.

As grandes concentrações de coliformes termotolerantes é o destaque do período chuvoso, apresentando números altos em todos os pontos, chegando a uma concentração de $7120 \mathrm{mg} / \mathrm{L}$ no ponto 5 
(Tabela 4). Ponto este em que foi encontrado lançamentos de efluentes domésticos, sendo um dos fatores que influencia no aparecimento de bactérias do grupo coliformes, principalmente os efluentes de origem sanitária (Figura 7).

De acordo com Lima (2018) os coliformes são os principais indicadores de contaminação da água, quando presentes em grandes quantidades podem indicar a ocorrência de microrganismos causadores de doenças de veiculação hídrica. Os demais parâmetros, como OD, pH, temperatura, turbidez, nitrogênio total e resíduo total estão todos dentro dos padrões no período chuvoso o que significa que não houve grandes alterações de um período para o outro. O OD ainda que dentro dos padrões estabelecidos, encontra-se com valores baixos, variando de 5 a $8,6 \mathrm{mg} / \mathrm{L}$ isso por conta da DBO que aumentou nesse período.

Tabela 4: Parâmetros físico-químicos e microbiológicos da segunda campanha de coleta de água - Período Chuvoso. Fonte: Pesquisa de campo.

\begin{tabular}{|c|c|c|c|c|c|c|c|c|c|c|c|c|}
\hline \multicolumn{13}{|c|}{ Pontos de coleta** } \\
\hline Parâmetro & Unid.* & P 1** & $\begin{array}{l}\mathrm{P} \\
2^{* *}\end{array}$ & $\begin{array}{l}\mathbf{P} \\
3^{* *}\end{array}$ & $\begin{array}{l}P \\
4 * *\end{array}$ & $\begin{array}{l}P \\
5 * *\end{array}$ & $\begin{array}{l}P \\
6 * \\
*\end{array}$ & $\begin{array}{l}\mathbf{P} \\
7^{* *}\end{array}$ & $\begin{array}{l}P \\
8 * *\end{array}$ & $\begin{array}{l}P \\
9 * *\end{array}$ & $\begin{array}{l}\mathrm{P} \\
10 * *\end{array}$ & $\begin{array}{l}\text { VMP } \\
* * *\end{array}$ \\
\hline OD & $\mathrm{mg} / \mathrm{L}$ & 7,9 & 6,4 & 5,2 & 5 & 7,6 & 6,5 & 7,7 & 8,3 & 8,5 & 8,6 & $\geq 5$ \\
\hline DBO & $\mathrm{mg} / \mathrm{L}$ & 8,5 & 8,6 & 8 & 8,1 & 11 & 7,9 & 7,2 & 7,1 & 7,2 & 8 & Até 5 \\
\hline Temperatura & ${ }^{\circ} \mathrm{C}$ & 24,6 & 24,8 & 24.3 & 24,6 & 24,7 & 24,6 & 26,5 & 25,5 & 25,7 & 25,3 & - \\
\hline Fósforo total & $\mathrm{mg} / \mathrm{L}$ & 1,38 & 1,54 & 1,24 & 2,39 & 2 & 0,86 & 1,46 & 2,16 & 1,73 & 1,43 & $\leq 0,1$ \\
\hline $\mathrm{pH}$ & & 7,7 & 8,9 & 7,6 & 7,2 & 7,1 & 7,1 & 6,9 & 7 & 6,9 & 7,1 & 6 a 9 \\
\hline Turbidez & UNT & 13,79 & $\begin{array}{l}25,0 \\
6 \\
\end{array}$ & $\begin{array}{l}37,5 \\
3\end{array}$ & 22,2 & $\begin{array}{l}26,2 \\
6\end{array}$ & 5,97 & $\begin{array}{l}91,0 \\
3\end{array}$ & $\begin{array}{l}19,8 \\
6 \\
\end{array}$ & $\begin{array}{l}28,5 \\
6\end{array}$ & 51,3 & $\begin{array}{l}\text { Até } \\
100\end{array}$ \\
\hline $\begin{array}{l}\text { Nitrogênio } \\
\text { Total }\end{array}$ & $\mathrm{mg} / \mathrm{L}$ & 0,1 & 0,26 & 0,1 & 0,1 & 0,52 & 0,2 & 0,1 & 0,1 & 0,2 & 0,2 & $\begin{array}{l}\text { Até } \\
2,18\end{array}$ \\
\hline Resíduo total & $\mathrm{mg} / \mathrm{L}$ & $\begin{array}{l}24,1 \\
2\end{array}$ & $\begin{array}{l}20,7 \\
7\end{array}$ & $\begin{array}{l}21,4 \\
4\end{array}$ & $\begin{array}{l}64,9 \\
9\end{array}$ & 20,1 & $\begin{array}{l}22,1 \\
1\end{array}$ & $\begin{array}{l}22,1 \\
1\end{array}$ & 24,79 & $\begin{array}{l}22,7 \\
8\end{array}$ & $\begin{array}{l}22,1 \\
1\end{array}$ & $\begin{array}{l}\text { Até } \\
500\end{array}$ \\
\hline $\begin{array}{l}\text { Coliformes } \\
\text { Termololerant } \\
\text { es }\end{array}$ & $\begin{array}{l}\text { UFC/100 } \\
\text { MI }\end{array}$ & $\begin{array}{l}96 \\
0\end{array}$ & 1840 & 1520 & $\begin{array}{l}112 \\
0\end{array}$ & 7120 & $\begin{array}{l}224 \\
0\end{array}$ & 2560 & $\begin{array}{l}184 \\
0\end{array}$ & $\begin{array}{l}208 \\
0\end{array}$ & $\begin{array}{l}264 \\
0\end{array}$ & $\begin{array}{l}\text { Ausent } \\
\mathrm{e}\end{array}$ \\
\hline
\end{tabular}

Índice de Qualidade das Águas (IQA)

Os valores de do Índice de Qualidade das Águas (IQA) observou-se que houve uma variação no período seco que se encontra entre 45 a 62, já o período chuvoso teve variação de 46 a 60 . No que diz respeito ao IQA do período seco este apresentou no ponto 1 um resultado que é considerado 'bom', já os demais pontos todos se enquadraram como aceitável (Tabela 5).

No período chuvoso alguns pontos como, pontos 1,6, 8 e 9 (Tabela 5), tiveram IQA classificado como 'bom', tal fato se dar por influência do Oxigênio Dissolvido (OD), onde houve aumento em alguns pontos. $O$ OD por ser um parâmetro com maior peso no índice do IQA (CETESB, 2017) acaba influenciando no aumento da qualificação dos trechos analisados. A diminuição do fósforo nesses pontos acabou influenciando também na qualificação dos mesmos.

Foi possível observar que mesmo com os valores altos de alguns parâmetros como DBO e coliformes termotolerantes, ainda assim o IQA ficou classificado como aceitável e bom. A DBO quando se encontra com altos valores pode indicar um aumento da microflora e interferir na manutenção e equilíbrio da vida aquática, e acabar ainda produzindo sabores e odores desagradáveis na água. A presença de coliformes 
termotolerantes na água pode indicar a existências de outros organismos, como os microrganismos patogênicos (CETESB, 2018).

Tabela 5: Síntese dos resultados do IQA do rio Corrente.

\begin{tabular}{l|l|l|l|l}
\hline Pontos de coleta & Valor do IQA & Classe IQA ${ }^{1}$ & Valor do IQA $^{2}$ & Classe IQA $^{2}$ \\
\hline Ponto 1 & 62 & Bom & 58 & Bom \\
\hline Ponto 2 & 52 & Aceitável & 50 & Aceitável \\
\hline Ponto 3 & 51 & Aceitável & 52 & Aceitável \\
\hline Ponto 4 & 51 & Aceitável & 51 & 49 \\
\hline Ponto 5 & 47 & Aceitável & 59 & Aceitável \\
\hline Ponto 6 & 49 & Aceitável & 59 & Bom \\
\hline Ponto 7 & Aceitável & 49 & Aceitável \\
\hline Ponto 8 & 45 & Aceitável & 54 & Bom \\
\hline Ponto 9 & 47 & Aceitável & 53 & Bom \\
\hline Ponto 10 & 46 & Aceitável & 51 & Aceitável
\end{tabular}

IQA 1 índice de qualidade das águas do período seco; IQA² - índice de qualidade das águas do período chuvoso.

Diante disso, é merecida uma análise crítica sobre essa metodologia bastante utilizada no Brasil. Essa preocupação também é ressaltada no trabalho de Passos et al. (2017), no qual ressaltam que os indicadores de qualidade da água no Brasil precisam passar por algumas mudanças, uma vez que nas regiões do país acontece uma variação dos parâmetros. Pois, muitas vezes o $\mathrm{pH}, \mathrm{OD}$ e demais parâmetros se distingue de uma região para outra. Os autores ainda ressaltam que 'o IQA é um conjunto de parâmetros objetivo, porém o mesmo não considera os usos múltiplos da água. Também não pondera as características especificas das regiões, o que pode torná-lo ineficiente por não se ajustar as condições de determinados corpos hídricos'. Apesar das críticas, o IQA é a metodologia mais utilizada e mais respeitada até o presente momento.

\section{CONCLUSÕES}

A Área de Preservação Permanente do Rio Corrente com base no Plano Diretor municipal deveria ser de 100 metros em cada margem de floresta natural totalizando 117,42 hectares. No ano de 1998 a APP correspondia a 39 hectares e no ano de 2018 um total de 60,8 hectares. Analisando os parâmetros de qualidade da água individualmente levando em consideração a Resolução no 357/2005 do CONAMA, muitos estão em desacordo, chamando atenção os coliformes termotolerantes e a DBO especialmente do ponto 5. Quando se analisa o índice de qualidade das águas (IQA) o mesmo apresenta classificação entre aceitável e bom.

Desta forma, as informações obtidas sinalizam que, apesar de estar aumentando a vegetação natural na área de preservação permanente e a qualidade de água ser em sua maioria aceitável, o poder público deve buscar efetivar o que está previsto no Plano Diretor Municipal, com a preservação das margens do rio de acordo com a lei, um melhor planejamento territorial e cumprir as metas de reflorestamento das margens do rio, que consequentemente vai refletir na qualidade da água, e também investir na educação ambiental como ferramenta de conscientização, pois com cidadãos conscientes temos uma maior efetividade da preservação dos recursos naturais. 


\section{REFERÊNCIAS}

ABREU, C. H. M.; CUNHA, A. C.. Qualidade da água e índice trófico em rio de ecossistema tropical sob impacto ambiental. Engenharia Sanitária e Ambiental, v.22, n.1, p.45-56. 2018. DOI: https://doi.org/10.1590/s1413$\underline{41522016144803}$

ADAPI. Agência de Defesa Agropecuária do Piauí. População bovina do estado do Piauí. Teresina: ADAPI, 2014.

AMARAL, D. S. S.; GARCIA, I. M.; ALMEIDA GIL, G.; POLLO, R. A.. Conflitos de uso e ocupação do solo em Áreas de Preservação Permanente no pré-assentamento baixa verde, e Eunápolis (BA), em 2015. Revista PINDORAMA, v.8, n.8, p.13-13, 2018.

AMÂNCIO, D. V.; COELHO, G.; MARQUES, R. F. D. P. V.; VIOLA M. R.; MELLO, C. R.. Qualidade da água nas sub-bacias hidrográficas dos Rios Capivari e Mortes, Minas Gerais. Scientia Agrária, v.19, n.1, p.75-86, 2018. DOI: http://doi.org/10.5380/rsa.v19i1.53175

APHA. American Public Health Association. Standard methods for the examination of water and wastewater. 22 ed. Washington: APHA, 2012.

BRASIL. Resolução n. 357/2005. Dispõe sobre a classificação dos corpos de águas e diretrizes ambientais para o seu enquadramento, bem como estabelece as condições padrões de lançamento de efluentes, promulgada em 17 de março de 2005. Brasília: DOU, 2005.

BRASIL. Lei n. 10.257: Regulamenta os art. 182 e 183 da Constituição Federal estabelece diretrizes gerais da política urbana e dá outras providências. Brasília: DOU, 2001.

BRASIL. Lei n. 9.433, de 8 de janeiro de 1997. Institui a Política Nacional de Recursos Hídricos, cria o Sistema Nacional de Gerenciamento de Recursos Hídricos, regulamenta o inciso XIX do art. 21 da Constituição Federal, e altera o art. 10 da Lei no 8.001, de 13 de março de 1990, que modificou a Lei no 7.990, de 28 de dezembro de 1989. Brasília: DOU, 1997.

BRASIL. Lei n. 394/2007 de 02 de outubro de 2007. Plano Diretor Participativo do Município de Corrente Piauí. Brasília: DOU, 2007.

BRASIL. Lei n. 12.651, de 25 de maio de 2012. Institui o novo código florestal brasileiro. Brasília: DOU, 2012.

BONAVIDES, P.. Curso de Direito Constitucional. 21 ed. São Paulo: Malheiros Ltda., 2017.

CAMPAGNOLO, K.. Área de Preservação Permanente de um rio e análise do Código Florestal Brasileiro. Dissertação (Mestrado) - Universidade Federal de Santa Maria, Santa Maria, 2013.

CARVALHO, A. A. A. A.. Avaliação das áreas de preservação permanente de curso d'água na área de proteção de manancial do Córrego Quinze, Distrito Federal. Dissertação (Mestrado em Geociências Aplicadas, Área de Concentração Geoprocessamento e Análise Ambiental) - Universidade de Brasília, Brasília, 2011.
CETESB; ANA. Companhia Ambiental do Estado de São Paulo; Agência Nacional de Águas. Guia nacional de coleta e preservação de amostras: água, sedimento, comunidades aquáticas e efluentes líquidas. São Paulo: CETESB; Brasília: ANA, 2011.

CETESB. Companhia Ambiental do Estado de São Paulo. Qualidade das águas interiores no estado de São Paulo. São Paulo: CETESB, 2017.

CETESB. Companhia Ambiental do Estado de São Paulo. Fundamentos do Controle de Poluição das Águas. São Paulo: CETESB, 2018.

FARIAS, E.; SILVA, J. R.; CAMARGO, P. L. T.. Mapeamento do uso e ocupação da terra de Santo Antônio do Monte/MG através de técnicas de geoprocessamento ao longo de 35 anos. Caminhos de Geografia, v.19, n.66, p.203-217, 2017. DOI: https://doi.org/10.14393/RCG196614

FUNCEME. Fundação Cearense de Meteorologia e Recursos Hídricos. Programa QualiGraf. Fortaleza: FUNCEME, 2018.

FONSÊCA, J. V. B.. Avaliação do uso e ocupação do solo na Área De Preservação Permanente Do Açude Pataxó/RN. Monografia (Bacharelado) - Universidade Federal do Rio Grande do Norte, Natal, 2019.

IBGE. Instituto Brasileiro de Geografia e Estatísticas. Corrente/PI, IBGE Cidades. Corrente: IBGE, 2019.

INMET. Instituto Nacional de Meteorologia. Estações Automáticas: Corrente/PI. Corrente: INMET, 2019.

LIMA, T. D. F. C.. Bacia hidrográfica córrego do Ferreirinha: análise do índice de qualidade da água. Intertemas Arq. Eng., 2018.

MORAIS, R. C. S.. Geoprocessamento Aplicado à Caracterização Morfométrica da Bacia Hidrográfica do Rio Corrente, Sul do Piauí. In: ENCONTRO DE PRODUTIVIDADE EM PESQUISA, 5; ENCONTRO DE INICIAÇÃO CIENTÍFICA, 5. Anais. 2013.

MOREIRA, T. R.; SANTOS, A. R. D.; DALFI, R. L.; CAMPOS, R. F. D.; SANTOS, G. M. A. D. A.; EUGENIO, F. C.. Confronto do uso e ocupação da terra em APPs no município de Muqui, ES. Floresta e Ambiente, v.22, n.2, p.141-152, 2015.

PASSOS, A. L. L.; OLIVEIRA FILHO, E. C.; MUNIZ, D. H. F.. Índices de qualidade da água no Brasil: uma avaliação crítica. In: WORKSHOP INTERNACIONAL SOBRE PLANEJAMENTO E DESENVOLVIMENTO SUSTENTÁVEL EM BACIAS HIDROGRÁFICAS, 6. Anais. Uberlândia: UFU, 2017.

ROCHA, A. A.; ZANELLA, G. B.. Avaliação da qualidade da água do Rio Santa Rosa, Francisco Beltrão/PR. Monografia (Bacharelado) - Universidade Tecnológica Federal do Paraná, Curitiba, 2016.

ROCHA, I. L.; SALOMÃO, L. C.; IWATA, B. F.; SOUZA, J. A. R.; MOREIRA, D. A.. Qualidade ambiental das nascentes do rio Paraim, extremo sul do Piauí. Revista Ibero-Americana de Ciências Ambientais, v.10, n.3, p.385-399, 2019. DOI: http://doi.org/10.6008/CBPC2179-6858.2019.003.0032 
SANO, E. E.. Mapeamento do uso do solo e cobertura vegetal: bioma cerrado: ano base 2010. Brasília: MMA, 2010.

SANTOS, R. C. L.; LIMA, Á. S.; CAVALCANTI, E. B.; MELO, C. M. D.; MARQUES, M. N.. Aplicação de índices para avaliação da qualidade da água da Bacia Costeira do Sapucaia em Sergipe. Engenharia Sanitária Ambiental, v.23, n.1, p.33-46, 2018. DOI: https://doi.org/10.1590/s1413-41522017159832

SILVA, F. L.. Carência de professores licenciados em matemática em Corrente: um estudo a partir das representações sociais. Tese (Doutorado em Educação: Conhecimento e Inclusão Social da Faculdade de Educação) Universidade Federal de Minas Gerais, Belo Horizonte, 2018.
SILVA, M. D. S.; BUENO, I. T.; ACERBI JÚNIOR, F. W.; BORGES, L. A. C.; CALEGARIO, N.. Avaliação da cobertura do solo como indicador de gestão de recursos hídricos: um caso de estudo na sub-bacia do Córrego dos Bois, Minas Gerais. Engenharia Sanitária e Ambiental, v.22, n.3, p.445-452.2017. DOI: https://doi.org/10.1590/s1413-41522017149673

TEIXEIRA, W.. Decifrando a terra. 2 ed. São Paulo: Companhia Nacional, 2009.

VIEIRA, M. R.. Os principais parâmetros monitorados pelas sondas multiparâmetros são: $\mathrm{pH}$, condutividade, temperatura, turbidez, clorofila ou cianobactérias e oxigênio dissolvido. ANA, 2015.

A CBPC - Companhia Brasileira de Produção Científica (CNPJ: 11.221.422/0001-03) detém os direitos materiais desta publicação. Os direitos referem-se à publicação do trabalho em qualquer parte do mundo, incluindo os direitos às renovações, expansões e disseminações da contribuição, bem como outros direitos subsidiários. Todos os trabalhos publicados eletronicamente poderão posteriormente ser publicados em coletâneas impressas sob coordenação da Sustenere Publishing, da Companhia Brasileira de Produção Científica e seus parceiros autorizados. Os (as) autores (as) preservam os direitos autorais, mas não têm permissão para a publicação da contribuição em outro meio, impresso ou digital, em português ou em tradução. 